\title{
ДОСЛІДЖЕННЯ МІНЕРАЛЬНОГО СКЛАДУ СЛАНЕЙ ПАРМЕЛІЇ ПЕРЛИНОВОї
}

Вступ. Пармелія перлинова - розповсюджений в усьому світі лишайник, який належить до родини пармелієві. В Аюрведичній медицині слані пармелії перлинової використовують для лікування ряду захворювань різного генезу. Літературні дані містять відомості про те, що представники родини пармелієві проявляють широкий спектр біологічної дії, зокрема мають антибактеріальну, кардіотонічну, спазмолітичну, антиоксидантну та іншу активність.

Мета дослідження - вивчити мінеральний склад сланей пармелії перлинової казахського та російського виробництва.

Методи дослідження. Для дослідження складу макро- і мікроелементів методом атомно-абсорбційної спектроскопії використовували слані пармелії перлинової казахського та російського виробництва.

Результати й обговорення. За результатами дослідження, встановлено вміст 19 мінеральних елементів у сланях пармелії перлинової казахського та російського виробництва. В обох досліджуваних об'єктах домінували такі елементи, як кальцій та силіцій. Вміст кальцію в сировині казахського виробництва становив 2270,00 мкг/100 г, російського - 1938,00 мкг/100 г. Вміст силіцію в цих зразках сировини дорівнював 1815,00 та 1619,00 мкг/100 г відповідно. Вміст фреруму та магнію в обох зразках був майже однаковим, а вміст калію і натрію в сировині російського виробництва - в 1,5 раза вищим, ніж у сировині казахського виробництва. Встановлено, що обидва зразки значною мірою накопичували манган та цинк. Вміст важких металів в обох зразках сировини був у межах гранично допустимих концентрацій для лікарської рослинної сировини та харчових продуктів відповідно до вимог діючого законодавства.

Висновок. Одержані результати можуть бути використані при розробці лікарських засобів на основі сланей пармелії перлинової та методів контролю якості цієї сировини.

КЛЮЧОВІ СЛОВА: мінеральні елементи; лишайник; пармелія перлинова; атомно-абсорбційна спектроскопія.

ВСТУП. Мінеральні елементи є життєво важливими речовинами, які беруть участь у ряді біохімічних процесів. Їх поділяють на макро- та мікроелементи залежно від добової потреби організму в них. Більшість мінеральних елементів в організмі людини бере участь у формуванні клітин і тканин, є кофракторами вітамінів, гормонів та підтримує гомеостаз. Крім того, натрій, кальцій та магній беруть участь у передачі нервово-м'язових імпульсів. Завдяки іонам феруму клітини крові переносять кисень, відбуваються процеси тканинного дихання. Іони цинку стимулюють транскрипцію генів, проявляють ранозагоювальну, антиоксидантну та гастропротекторну дію $[1,2]$.

Пармелія перлинова (Parmelia Perlata (Huds.) Ach.) є симбіотичною асоціацією грибів та водоростей і належить до родини пармелієві. В Аюр(с О. А. Кисличенко, В. В. Процька, І. О. Журавель, 2018. ведичній медицині слані пармелії перлинової використовують для загоєння ран, лікування інфекційних та запальних захворювань, дизентерії, кашлю, бронхітів, лихоманки, псоріазу, аменореї, лейкореї. їх застосовують при посиленому слиновиділенні, облисінні, нічному енурезі, блюванні, діареї, диспепсії, хворобах серця, зубному та головному болю, корості, вошах і проказі [3-5].

За даними літератури, представники родини пармелієві містять полісахариди, жирні кислоти, фенольні й терпенові сполуки, стероїди, які проявляють антимікробну, анальгетичну, відхаркувальну, жарознижувальну, антидіабетичну, кардіотонічну, спазмолітичну, противірусну, літолітичну, протипухлинну та антиоксидантну активність [3-5, 6-9].

Проте хімічний склад сланей пармелії перлинової досліджено недостатньо, а методи конт- 
ролю якості цієї сировини в Україні відсутні, що підтверджує перспективність поглибленого фрітохімічного вивчення пармелії перлинової.

Мета дослідження - вивчити мінеральний склад сланей пармелії перлинової казахського та російського виробництва.

МЕТОДИ ДОСЛІДЖЕННЯ. ВИвчали мінеральний склад сланей пармелії перлинової казахського (ТОВ “Зерде-Фіто”, Казахстан) та російського (ТОВ “Азбука трав", Росія) виробництва.

Для вивчення мінерального складу пробу сировини попередньо обробляли розведеною сульфратною кислотою та обережно обвуглювали в мусрельній печі, температура якої не перевищувала $500{ }^{\circ} \mathrm{C}$. Проби випаровували з кратерів грасрітових електродів у розряді дуги перемінного струму (джерело збудження спектрів типу IBC-28) при силі струму 16 А й експозиції 60 с. Одержані спектри реєстрували на фротопластинках спектрографра ДФС-8 3 дифракційною решіткою 600 штр/мм і трилінзовою системою висвітлення щілини. Інтенсивність ліній спектрів і градуювальних зразків (ГЗ) вимірювали з використанням мікросротометра МФ-1 [10].

Спектри фротографували за таких умов: сила струму дуги перемінного струму становила 16 A, фраза підпалу - 60, частота підпалювальних імпульсів - 100 розрядів за секунду; аналітичний проміжок-2 мм; ширина щілини спектрографра 0,015 мм; експозиція - 60 с. Спектри фротографрували в ділянці 230-330 нм [10].
Фотопластинки проявляли, сушили, потім фотометрували наступні лінії (нм) у спектрах проб і ГЗ, а також фрон біля них [10].

Для кожного елемента, за результатами фротометрування, розраховували різницю почорніння лінії і фрону $\left(S=S_{л+\phi}-S_{\phi \phi}\right)$ для спектрів проб $\left(S_{i н}\right)$ та ГЗ $\left(S_{\Gamma 3}\right)$.

Потім будували градуювальний графік у координатах: середнє значення різниці почорніння лінії і фрону $\left(S_{\ulcorner з}\right)$ - логариорм вмісту елемента в ГЗ $(\lg C)$, де C виражено у відсотках до основи [10].

Вміст елемента в золі (\%) визначали за графріком, вміст елемента в досліджуваному матеріалі $(X, \%)$ - за фрормулою:

$$
X=\frac{a \cdot m}{M}
$$

де $m$ - маса золи (г); $M$ - маса сировини (г); a - вміст елемента в золі (\%) [10].

РЕЗУЛЬТАТИ Й ОБГОВОРЕННЯ. У резУЛЬтаті експерименту в обох досліджуваних зразках ідентифрікували та визначили кількісний вміст 19 мінеральних елементів. Результати аналізу наведено в таблиці та зображено на рисунку.

За вмістом макро- і мікроелементів обидва досліджувані зразки відрізнялись незначно. Загальний вміст мінеральних елементів у зразку казахського виробництва становив 5578,47 мкг/100 г, російського - 5287,57 мкг/100 г.

В обох досліджуваних зразках пармелії перлинової домінували такі елементи, як кальцій та силіцій. Їх вміст у зразку казахського вироб-

Таблиця - Вивчення мінерального складу сланей пармелії перлинової казахського та російського виробництва

\begin{tabular}{|c|l|c|c||}
\hline \multirow{2}{*}{ № } & \multirow{2}{*}{ Назва елемента } & \multicolumn{2}{|c|}{ Вміст мінеральних елементів, мкг/100 г } \\
\cline { 3 - 4 } & & сировина казахського виробництва & сировина російського виробництва \\
\hline 2 & Ферум & 340,00 & 327,00 \\
\hline 3 & Фосфрор & 1815,00 & 1619,00 \\
\hline 4 & Алюміній & 23,00 & 44,00 \\
\hline 5 & Манган & 130,00 & 150,00 \\
\hline 6 & Магній & 17,00 & 27,00 \\
\hline 7 & Плюмбум & 455,00 & 432,00 \\
\hline 8 & Нікол & 0,05 & 0,05 \\
\hline 9 & Молібден & $<0,03$ & $<0,03$ \\
\hline 10 & Кальцій & $<0,03$ & $<0,03$ \\
\hline 11 & Купрум & 2270,00 & 1938,00 \\
\hline 12 & Цинк & 0,60 & 0,90 \\
\hline 13 & Натрій & 45,00 & 41,00 \\
\hline 14 & Калій & 230,00 & 330,00 \\
\hline 15 & Стронцій & 230,00 & 359,00 \\
\hline 16 & Кобальт & 22,70 & 19,50 \\
\hline 17 & Кадмій & $<0,03$ & $<0,03$ \\
\hline 18 & Арсен & $<0,01$ & $<0,01$ \\
\hline 19 & Меркурій & $<0,01$ & $<0,01$ \\
\hline Загальний вміст мінераль- & $<0,01$ & $<0,01$ \\
\hline них елементів & 5578,47 & 5287,57 \\
\hline
\end{tabular}



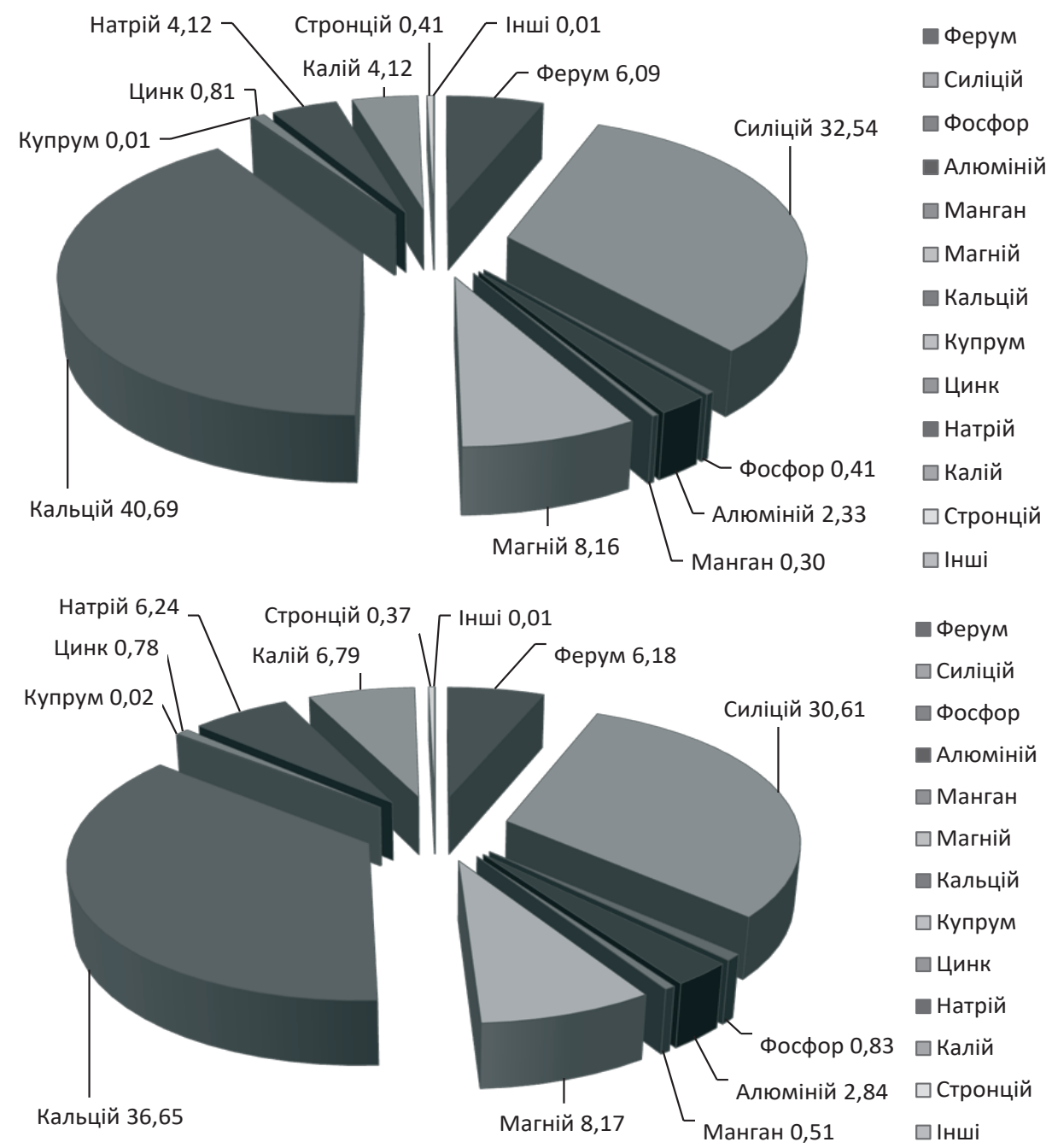

Рис. Вміст мінеральних елементів у сланях пармелії перлинової в перерахунку на суму мінеральних елементів серед усіх визначених: А - казахського виробництва; Б - російського виробництва.

ництва становив 2270,00 та 1815,00 мкг/100 г, російського - 1938,00 і 1619,00 мкг/100 г відповідно.

У сланях пармелії перлинової казахського виробництва у великій кількості накопичувались магній (455,00 мкг/100 г) та фрерум (340,00 мкг/100 г). Вміст калію та натрію в цьому зразку сировини становив по 230,00 мкг/100 г.

У сировині пармелії перлинової російського виробництва відмічено значний вміст магнію (432,00 мкг/100 г), калію (359,00 мкг/100 г), натрію (330,00 мкг/100 г) та фреруму (327,00 мкг/100 г). Причому вміст магнію та феруму в обох зразках сировини був майже однаковим, а вміст калію і натрію в сланях пармелії перлинової російського виробництва - в 1,5 раза вищим.

У сланях пармелії перлинової казахського та російського виробництва виявлено значний вміст цинку $(45,00$ та 41,00 мкг/100 г) і мангану $(17,00$ та 26,00 мкг/100 г).

Вміст важких металів в обох досліджуваних зразках сировини був у межах гранично допус- тимих концентрацій для лікарської рослинної сировини і харчових продуктів відповідно до Закону України "Про основні принципи та вимоги до безпечності та якості харчових продуктів" і наказу Міністерства охорони здоров'я України “Про затвердження Державних санітарних норм та правил "Медичні вимоги до якості та безпечності харчових продуктів та продовольчої сировини" $[11,12]$.

ВИСНОВКИ. 1. Методом атомно-абсорбційної спектроскопії у зразках сировини пармелії перлинової казахського таросійського виробництва визначено вміст 19 мінеральних елементів.

2. Загальний вміст мінеральних елементів у досліджуваних зразках відрізнявся незначно. В обох об'єктах домінували такі елементи, як кальцій та силіцій.

3. Вміст магнію та фоеруму в сланях пармелії перлинової обох виробників був однаковим, а вміст калію і натрію в сировині російського виробництва - в 1,5 вищим. Встановлено, що в 
обох видах сировини значною мірою накопичувалися манган та цинк.

4. Вміст важких металів був у межах гранично допустимих концентрацій для лікарської рослинної сировини та харчових продуктів.
5. Одержані результати можуть бути використані при розробці лікарських засобів на основі сланей пармелії перлинової та методів контролю якості цієї сировини.

\section{СПИСОК ЛІТЕРАТУРИ}

1. Importance of luminal and mucosal Zinc in the mechanism of experimental gastric ulcer healing / W. Opoka, D. Adamek, M. Plonka [et al.] // Journal of Physiology and Pharmacology. - 2010. - 61, No. 5. P. 581-591.

2. Soetan K. O. The importance of mineral elements for humans, domestic animals and plants: A review / K. O. Soetan, C. O. Olaiya, O. E. Oyewole // African Journal of Food Science. - 2010. - 4 (5). - P. 200-222.

3. Pharmacological and phytochemical aspects of lichen Parmelia Perlata: a review / Goyal Parveen Kumar, Verma Santosh Kumar, Sharma Anil Kumar [et al.] // International Journal of Research in Ayurveda and Pharmacy. - 2016. - No. 7. - P. 102-107.

4. Sneha Paul. An antioxidant and bioactive compound studies of Parmelia perlata, Ganoderma lucidum and Phellinus i gniarius - supplimentory drug / Sneha Paul, Anita R. J. Singh, Changam Sheela Sasikumar // Asian Journal of Pharmaceutical Technology \& Innovation. - 2014. - No. 02 (07). - P. 13-22.

5. Vidyalakshmi Alwar. Antibacterial activity of Parmelia perlata / Vidyalakshmi Alwar, Kruthika Kandaswamy // Asian Pacific Journal of Tropical Biomedicine. 2012. - No. 12. - P. 892-894.

6. Nedeljko Manojlovi. Chemical composition of three Parmelia lichens and antioxidant, antimicrobial and cytotoxic activities of some their major metabolites / Nedeljko Manojlovi, Branislav Rankovi, Marijana Kosani // Phytomedicine. - 2012. - No. 19. - P. 1166-1172.

7. Rauf Abdur. Study on extracts of Parmelia perlata Ach. for its antimicrobial potential against certain microorganisms / Rauf Abdur, Latif Abdul, Rehman Sumbul //
International Research Journal of Pharmacy. - 2013. No. 4 (11). - P. 102-106.

8. Sharma Anil K. Phytochemical investigation of therapeutic important lichen: Parmelia perlata/K. M. Sharma Anil, C. Sharma, M. P. Dobha // Journal of Natural Product and Plant Resource. - 2012. - No. 2 (1). P. 101-106.

9. Stojanović1 Igor Z. Volatile constituents of selected Parmeliaceae lichens / Z. Stojanović1 Igor, S. Radulović Niko, L. J. Mitrović Tatjana // Journal of the Serbian Chemical Society. -2011. - No. 76 (7). -P. 987 994.

10. The study of micro- and macroelements composition of Quince (Cydonia Oblonga) plant material / F. Dababneh Moeen, V. Grinenko Uliana, S. Almuaikel Nayef [et al.] // Research Journal of Pharmaceutical, Biological and Chemical Sciences. - 2017. - No. 8 (2). P. 1830-1832.

11. Про основні принципи та вимоги до безпечності та якості харчових продуктів : Закон України від 22.07.2014 р. № 1602-VII [Електронний ресурс]. Режим доступу : http://zakon5.rada.gov.ua/laws/ show/771/97-\%D0\%B2\%D1\%80/page (дата звернення 20.01.2018 р.). Назва з екрана.

12. Про затвердження Державних санітарних норм та правил "Медичні вимоги до якості та безпечності харчових продуктів та продовольчої сировини" : наказ Міністерства охорони здоров'я України від 09.01.2013 р. № 1140 [Електронний ресурс]. - Режим доступу : http://zakon5.rada.gov.ua/laws/show/z008813/paran14\#n14 (дата звернення 20.01.2018р.). Назва $з$ екрана.

\section{REFERENCES}

1. Opoka, W., Adamek, D., \& Plonka, M. (2010). Importance of luminal and mucosal Zinc in the mechanism of experimental gastric ulcer healing. Journal of Physiology and Pharmacology, 61 (5), 581-591.

2. Soetan K.O., Olaiya C.O., \& Oyewole O.E. (2010) The importance of mineral elements for humans, domestic animals and plants: A review. African Journal of Food Science, 4 (5), 200-222.

3. Goyal Parveen Kumar, Verma Santosh Kumar, \& Sharma Anil Kumar (2016). Pharmacological and phytochemical aspects of lichen Parmelia Perlata: a review.
International Journal of Research in Ayurveda and Pharmacy, 7, 102-107.

4. Sneha Paul, Anita R.J. Singh, Changam Sheela Sasikumar (2014). An antioxidant and bioactive compound studies of Parmelia perlata, Ganoderma lucidum and Phellinus i gniarius - supplimentory drug. Asian Journal of Pharmaceutical Technology \& Innovation, 02 (07), 13-22.

5. Vidyalakshmi Alwar, \& Kruthika Kandaswamy (2012). Antibacterial activity of Parmelia perlata. Asian Pacific Journal of Tropical Biomedicine, 12, 892-894. 
6. Nedeljko Manojlovi, Branislav Rankovi, \& Marijana Kosani (2012). Chemical composition of three Parmelia lichens and antioxidant, antimicrobial and cytotoxic activities of some their major metabolites. Phytomedicine, 19, 1166-1172.

7. RaufAbdur, LatifAbdul, \& Rehman Sumbul (2013). Study on extracts of Parmelia perlata Ach. for its antimicrobial potential against certain microorganisms. International Research Journal of Pharmacy, 4 (11), 102-106.

8. Sharma Anil K., Sharma M.C., \& Dobha, M.P. (2012). Phytochemical investigation of therapeutic important lichen: Parmelia perlata. Journal of Natural Product and Plant Recourse, 2 (1), 101-106.

9. Stojanović1 Igor Z., Radulović Niko S., Mitrović Tatjana LJ. (2011). Volatile constituents of selected Parmeliaceae lichens. Journal of the Serbian Chemical Society, 76 (7), 987-994.

10. Dababneh Moeen F., Grinenko Uliana V., Almuaikel Nayef S., Zhuravel Iryna O. (2017). The study of micro- and macroelements composition of Quince (Cydonia Oblonga) plant material. Research Journal of Pharmaceutical, Biological and Chemical Sciences, 8 (2), 18301832.

11. Zakon Ukrainy "Pro osnovni pryntsypy ta vymohy do bezpechnosti ta yakosti kharchovykh produktiv" v redaktsii № 1602-VII vid 22.07.2014. Retrieved from: http://zakon5.rada.gov.ua/laws/show/771/97\%D0\%B2\%D1\%80/page. (Data zvernennia 20.01.2018). Nazva z ekranu [in Ukrainian].

12. Nakaz Ministerstva okhorony zdorovia Ukrainy "Pro zatverdzhennia Derzhavnykh sanitarnykh norm ta pravyl "Medychni vymohy do yakosti ta bezpechnosti kharchovykh produktiv ta prodovolchoi syrovyny" № 1140 vid 09.01.2013 roku. Retrieved from: http:// zakon5.rada.gov.ua/laws/show/z0088-13/paran14\#n14. (Data zvernennia 20.01.2018). Nazva z ekranu [in Ukrainian].

\section{ИССЛЕДОВАНИЕ МИНЕРАЛЬНОГО СОСТАВА СЛОЕВИЩ ПАРМЕЛИИ ЖЕМЧУЖНОЙ}

\section{Резюме}

Вступление. Пармелия жемчужная - распространенный во всем мире лишайник, который относится к семейству пармелиевые. В Аюрведической медицине слоевища пармелии жемчужной используют для лечения ряда заболеваний различного генеза. Литературные данные содержат сведения о том, что представители семейства пармелиевые проявляют широкий спектр биологчческого действия, в частности имеют антибактериальную, кардиотоническую, спазмолитическую, антиоксидантную и другую активность.

Цель исследования - изучить минеральный состав слоевищ пармелии жемчужной казахского и российского производства.

Методы исследования. Для исследования состава макро- и микроэлементов методом атомно-абсорбционной спектроскопии использовали слоевища пармелии жемчужной казахского и российского производства.

Результаты и обсуждение. По результатам исследования, установлено содержание 19 минеральных элементов в слоевищах пармелии жемчужной казахского и российского производства. Во всех исследуемых объектах доминировали такие элементы, как кальций и кремний. Содержание кальция в сырье казахского производства составлял 2270,00 мкг/100 г, российского - 1938,00 мкг/100 г. Содержание кремния в этих образцах сырья равнялся 1815,00 и 1619,00 мкг/100 г соответственно. Содержание железа и магния в обоих образцах было почти одинаковым, а содержание калия и натрия в сырье российского производства - в 1,5 раза выше, чем в сырье казахского производства. Установлено, что оба образца в значительном количестве накапливали марганец и цинк. Содержание тяжелых металлов в обоих образцах сырья было в пределах гранично допустимых концентраций для лекарственного растительного сырья и пищевых продуктов соответственно требованиям действующего законодательства.

Вывод. Полученные результаты могут быть использованы при разработке лекарственных средств из слоевищ пармелии жемчужной и методов контроля качества этого сырья.

КЛЮЧЕВЫЕ СЛОВА: минеральные элементы; лишайник; пармелия жемчужная; атомно-абсорбционная спектроскопия. 


\section{THE STUDY OF THE MINERAL COMPOSITION OF PARMELIA PERLATA THALLI}

\section{Summary}

Introduction. Parmelia perlata is a widespread lichen that belongs to the Parmeliaceae family. In Ayurvedic medicine thalli of Parmelia perlata are used for the treatment of a series of diseases of different genesis. Literature data contain information that the representatives of Parmeliaceae family show a wide spectrum of biological activity, in particular, possess anti-bacterial, cardiotonic, spasmolytic, antioxidant and other types of activity.

The aim of the study - to learn the mineral composition of parmelia perlata thalli of Kazakh and Russian production.

Materials and Methods. For the study of the composition of micro- and macroelements by the atomic-absorption spectroscopy method Parmelia perlata thalli of Kazakh and Russian production were used.

Results and Discussion. As a result of the study the content of 19 mineral elements in Parmelia perlata thalli of Kazakh and Russian production was determined. The dominating elements in both studied objects were calcium and silicon. The content of calcium in the raw material of Kazakh production comprised $2270.00 \mu \mathrm{g} / 100 \mathrm{~g}$, and in the raw material of Russian production $-1938.00 \mu \mathrm{g} / 100 \mathrm{~g}$. The content of silicon in the raw materials studied comprised $1815.00 \mu \mathrm{g} / 100 \mathrm{~g}$ and $1619.00 \mu \mathrm{g} / 100 \mathrm{~g}$ respectively. The content of iron and magnesium in both samples was almost identical, while the content of sodium and potassium in the raw material of Russian production was 1.5 times higher than in the raw material of Kazakh production. Both samples were found to accumulate magnesium and zinc in quite high concentration. The content of heavy metals in both raw material samples was within the limit of maximum permissible concentration for medicinal plant material and food products according to the requirements of the current legislation.

Conclusions. The obtained results can be used at working out medicines on the basis of Parmelia perlata thalli and the quality control methods for the raw material.

KEY WORDS: mineral elements; lichen; Parmelia perlata; atomic-absorption spectroscopy.

Отримано 24.01.18

Адреса для листування: В. В. Процька, Національний фармацевтичний університет, вул. Пушкінська, 53, Харків, 61002, Україна, e-mail:vvprotskaya@gmail.com. 